\title{
REAL ESTATE CROWDFUNDING PLATFORMS: BETWEEN RISKS AND REWARDS
}

\author{
Nicolae NISTOR ${ }^{a *}$, Carmen T,URLEA ${ }^{b}$ \\ ${ }^{a}{ }^{b}$ Bucharest University of Economic Studies, Romania
}

DOI: $10.24818 / \mathrm{IMC} / 2020 / 05.16$

\begin{abstract}
In the context of the financial constraints during the financial crisis of 2007-2008, the first crowdfunding real estate platforms begin to appear. They soon became real alternatives to traditional sources of financing for real estate projects, much more accessible to retail investors.

The purpose of this paper is to review the study of crowdfunding real estate platforms: what they are, what are the main operating models, what are the benefits and risks associated. In an attempt to understand the state of affairs of real estate platforms, we made a comparative analysis of seven major European platforms. Real estate platforms are relatively young, but offer higher returns than traditional investments, and the growth prospects are high.
\end{abstract}

KEYWORDS: crowdfunding platform, investment, real estate.

\section{INTRODUCTION}

The evolution of information and communication technology has produced major changes on the classic business models. Around 2010, in the real estate sector, the first fintech in real estate crowdfunding begin to appear. These covered a gap for the need to finance real estate projects, and so the market began to be attracted to this phenomenon.

Investments through these platforms represent a new paradigm, a real alternative to traditional sources of financing, but also a way to obtain higher returns on investment.

Because this method of financing is a relatively new trend, and changes are occurring rapidly, the literature covers very little of what an investment through such a platform currently means. Through this paper we want to contribute to the study of these types of investments, especially on the benefits and associated risks for investors and beneficiaries.

\section{CROWDFUNDING PLATFORMS - NEW WAYS TO FINANCE REAL ESTATE PROJECTS}

\subsection{What is crowdfunding}

Crowdfunding is a fast-growing industry around the world, and represents great potential for both investors and individuals or companies seeking financing. The Oxford Dictionary describes crowdfunding as, "the practice of funding a project or venture by raising many small amounts of money from a large number of people, typically via the Internet” („Crowdfunding”, 2020). The Internet has the potential to significantly reduce the cost of bringing together small investments and make it easier for individuals to target specific opportunities (Vogel \& Moll, 2014). Crowdfunding aims to raise funds to launch a product, project or start a business, through small contributions from a large number of participants, often in exchange for ensuring the future acquisition of products, shares or even securities (Shahrokhi, 2018). In a study by Ernst \& Young (2019), crowdfunding is

\footnotetext{
* Corresponding author. E-mail address: nistornicolae15@stud.ase.ro
} 
defined as a collection of equity and debt that must be invested in several types of projects through a web-based platform, able to create opportunities by facilitating a links between lenders and sponsors.

The history of crowdfunding platforms begins in the 2000s, when the first platforms began to appear (Shahrokhi, 2018), such as:

- 2005 Kiva ${ }^{\circledR}$ - gave individuals the opportunity to provide small loans to small businesses in poor areas of the world;

- 2006 Prosper ${ }^{\circledR}$ - the first peer-to-peer loan market in the USA was established;

- 2008 Indiegogo ${ }^{\circledR}$ - allowed people to easily donate funds by eliminating intermediaries;

- 2009 Kickstarter ${ }^{\circledR}$ - a platform through which creative projects are funded.

An important moment in the history of crowdfunding platforms is the adoption of the Jumpstart Our Business Startups Act (JOBS Act) in 2012, which relaxed the restrictive regulations for raising capital in the USA (Schweizer \& Zhou, 2016).

A common structure of crowdfunding platforms involves 3 major stakeholders (see Figure 1): Crowdfunder (financier, investor, donor and, in some cases, private and public institutions), beneficiaries (small companies, NGOs, Start-ups, projects, individuals) and the web platform (which brings together beneficiaries and investors in exchange for commissions).

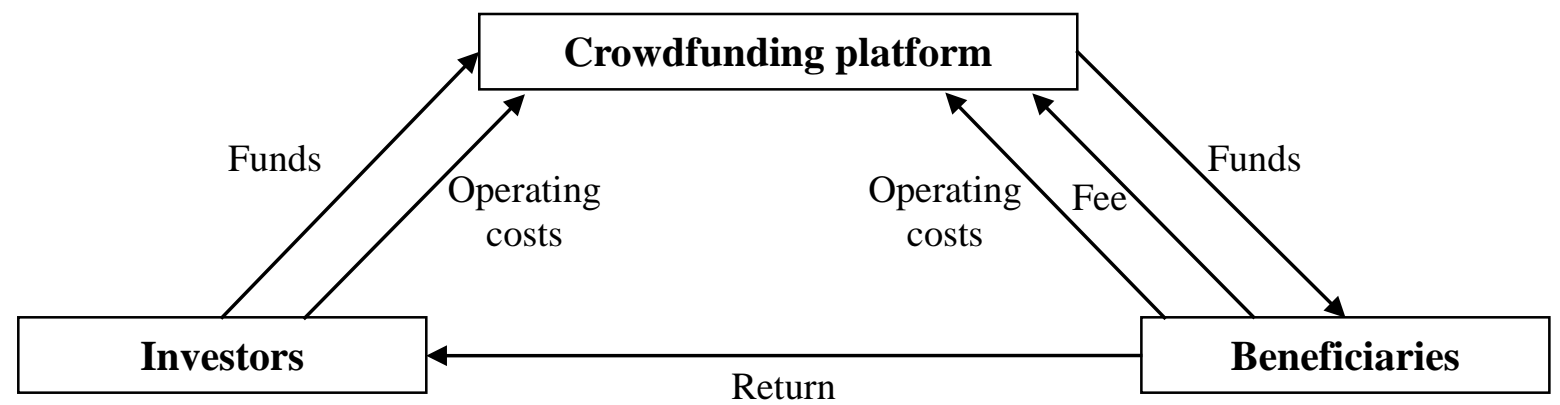

Figure 1. A typical Crowdfunding structure

Source: adapted from Ernst \& Young (2019)

In order to run a crowdfunding campaign, a series of operational costs incurred by beneficiaries or investors are involved. These include the commission charged by the platform, between 3 and 8\% (Ernst \& Young, 2019), accounting fees, legal costs, costs related to the control of project feasibility, marketing costs and various other services.

\subsection{Crowdfunding platforms in Real Estate}

The financial crisis of 2007 has shown us that investments in real estate are not the safest, and their value is not constantly growing (Baker, 2008). In the context of the financial crisis, amid the constraints on ongoing loans, crowdfunding platforms appear for the first time in an organized form, as a new way of financing a project, without the involvement of traditional creditors (GarciaTeruel, 2019). Their use in financing real estate projects (Real Estate Crowdfunding - RECF henceforth) has developed a lot in recent years. RECF is fast becoming a funding alternative to traditional channels. In fact, it is the fastest growing crowdfunding segment, after exceeding the volume of $\$ 1$ billion in 2014 and \$ 2.5 billion in 2015 (Massolution, 2015). According to the Ernst \& Young (2019) study, this segment amounted to \$ 4 billion in 2016 and is projected to reach \$ 9 billion by 2021 (see Figure 2), with a compound annual growth rate (CAGR) of 18,5\%. 


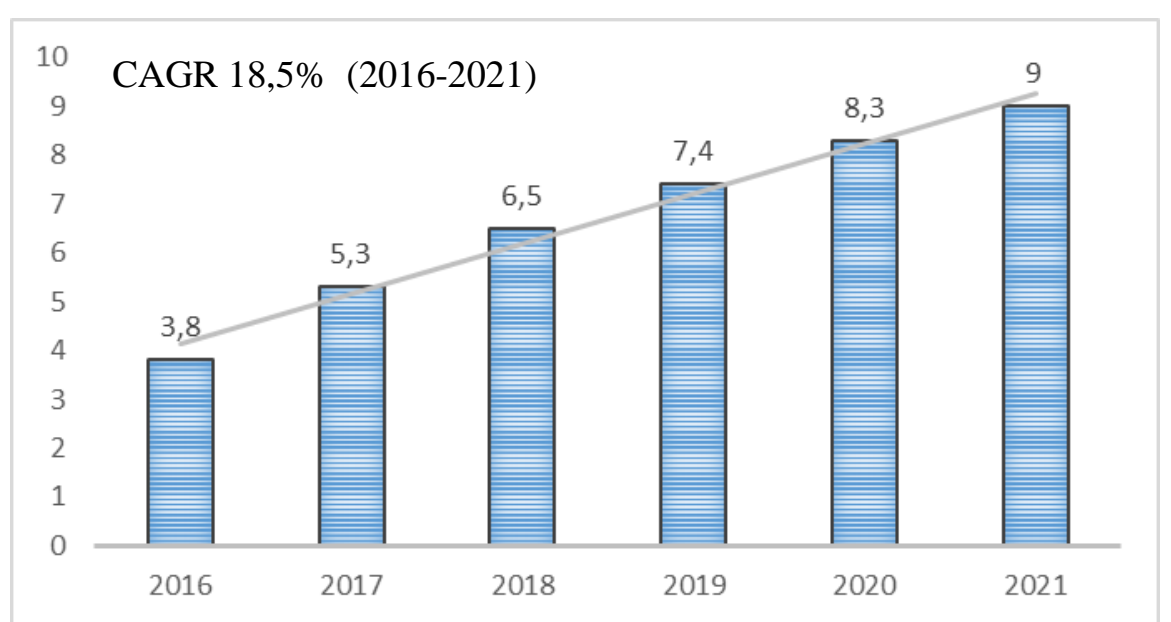

Figure 2. Evolution of the global Real Estate crowdfunding market (2016-2021) - \$ bn Source: adapted from Ernst \& Young (2019)

Because there are different types of crowdfunding platforms, each is represented by a crowdfunding model. Due to this fact, there are also in the real estate sector several crowdfunding schemes offered to investors, each with its own specificities.

However, one of the most common types, according to Garcia-Teruel (2019) is the one based on equity, through which the developer offers investors shares in the company. In equity real estate crowdfunding, three players are usually involved: the project promoter, ie the person or entity launching the project to purchase or renovate a particular building; the persons (the crowd) acting as investors (called retail investors), who provide the financial resources necessary for the development of the construction project; and, finally, the crowdfunding platform - the intermediary - the one that publishes the projects of the promoters and provides the essential information to the investors, among other commitments, such as checking the viability of the project (Baker, 2015). Once the necessary financial resources for the project have been obtained, an ad hoc company is created and investors receive shares in the new company. The purpose of this company is to buy a property, renovate it when needed and to rent it. The process ends when the property is sold and the profit is marked. Thus, crowdfunding investors will receive the returns obtained from renting the property and the value attributed after the sale of the building by the number of shares. After this phase, the company is liquidated (see Figure 3).

From these deals, investors expect an annual interest rate of between $7 \%$ and $10 \%$ and a return on capital at maturity (Vogel \& Moll, 2014). There are several famous platforms on the market for this business model, including Realty Mogul, Realty Shares, iFunding.

Although this model was very common and used when RECF appeared in 2012, many platforms have been developed and, implicitly, many other models. Thus, investors have other options in the field of RECF.

Crowdlending (or Peer 2 Peer lending) is a new form of intermediation with a fairly significant potential to compete with traditional financing, through which retail investors can offer loans to beneficiaries (developers, companies, individuals). Moreover, the European Central Bank (2015) includes crowdlending in the list of alternative sources of financing due to its potential to meet the needs of small and medium-sized enterprises, in a real, innovative way and with an increasing popularity (Borrero-Domínguez et al., 2020). These investments in debt, or loans, are linked to one or more properties and are secured by them until repayment (Shahrokhi, 2018). The developer usually uses the money collected to buy a property, in order to sell it profitably. After the sale, investors will receive their money back plus the agreed interest (Garcia-Teruel, 2019). Examples of platforms that use this model: Sharestates (US) with about \$ 1.56 bn attracted, Patch of Land (US) with $\$ 725 \mathrm{mn}$ attracted. 


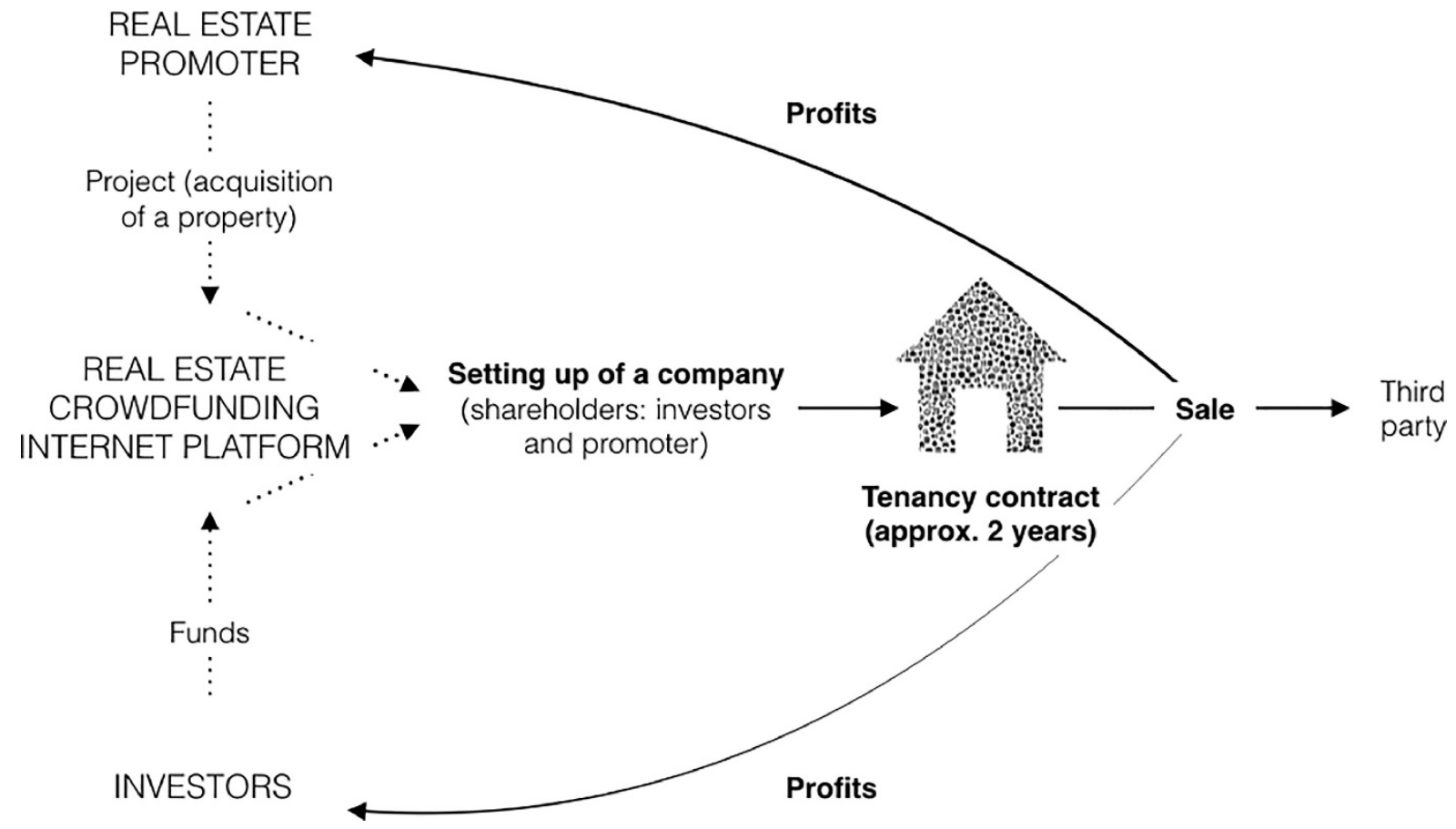

Figure 3. Equity-based real estate crowdfunding

Source: Garcia-Teruel, 2019

Another model often used by RECF is through smart real estate investment trusts (REITs), called eREIT/iREIT. Hu (2017) defines iREITs/eREITs as "a digital smart financial real estate Crowdfunding platform making the REITs accessible and affordable for anybody to invest anywhere and anytime with promising return from real-estate market, and without taking the risk of the volatile nature of the stock market ". This system combines crowdfunding and traditional REITs and allows investors to participate directly in a REIT. This provides greater security, as returns do not depend on a single property, having a portfolio of many other properties. The first eREIT, the Fundrise Real Estate Investment Trust, was launched on December 3, 2015 (Cassel, 2019). The offers for the company's investment projects are not traded on the public market, but are addressed to a private market. Fundrise charges a trading fee of $0.1 \%$ and zero fees for investors who earn annual returns below 15\%. As a comparison with the classic REITs, iREIT offered $90 \%$ lower fees (Hu, 2017).

\section{BENEFITS AND RISKS FOR INVESTORS AND PROMOTERS}

\subsection{Benefits}

Real estate crowdfunding platforms are starting to attract the attention of investors, because they offer much easier access to a financing of real estate projects, with a minimum participation. This interest in RECF is reflected by the annual increase in the amounts attracted by these platforms, with a CAGR of approximately 19\%. Minimum investment starts at 10 euro, according to Crowdfunding-platforms.com (2020), which gives investors the freedom to diversify their portfolio across several types of properties, countries or currencies and thus reducing the risk of investment (Schmidt, 2019). At the same time, many more investors are attracted because they want to diversify their investment portfolio and allocate a percentage for these types of investments. The study conducted by EY (2019) shows that investments made by investors guarantee an average return between $10 \%$ and $15 \%$. This return is very attractive for investors, superior to traditional investments. Among the advantages of using RECF by the promoter is the fact that it can launch a 
project independent of a bank or a single creditor. This helps a lot the companies that are at the beginning of the road and have financial constraints, and the bank cannot provide them with the necessary funds. At the same time, the promoter benefits from reduced costs and fees, compared to those charged by banks.

Another advantage for developers is the creation of a network of investors and business partners who contribute to the financing of the project as quickly as possible (Schmidt, 2019).

One important benefit, both for investors and promoters, is the transparency of the RECF platform (Vogel \& Moll, 2014). Investors can choose from a lot of projects based on their profitability, taking into account the location, developer, associated risk, and the promoter/sponsor, in turn, can track the status of attracting the necessary funds, can launch project promotion campaigns, can follow the interest shown for the project etc..

\subsection{Risks}

Any investment comes with a higher or lower level of risk, and investments through RECF platforms are no exception. If we analyze the two most common models for RECF platforms, equity-based and lending-based, the associated risks differ substantially.

The success of investments through platforms that operate on equity model is closely correlated with the variable share price. If the project in which investors put money does not meet expectations, most likely the difference between the invested capital and the output value will be a loss for investors. Thus, a major risk is when the real estate project fails, and the investor may lose some or all of the money (Schmidt, 2019).

Another risk of the equity model is the inaccurate duration of the investment. Some projects can be completed even in 5-10 years, and all this time the money is blocked in the investment.

Some investors with shares in the newly created company may come into conflict with other investors regarding the decisions related to the property in which they have invested. For example, if some investors want to sell a property after a year of rent, and another party wants to extend the contract for another year, conflicts can arise.

Using this model, the returns are higher, but so are the risks. The investor will be the last to be paid, and if the project is not profitable, the yield is very low, or not at all (see figure 4).

In the case of lending-based RECF platforms, a common risk is late payments. Delayed interest or principal payments are some of them. According to Crowdestor, one of the reasons for the late payments is the non-payment by other subcontractors, customers, and many other parties involved.

Unlike traditional bank loans, the developer will not be required to register a mortgage on the asset, which is usually required when applying for a loan of significant value. Therefore, the participating financiers are exposed to a major risk, because the loan will not be guaranteed by a mortgage loan (Garcia-Teruel, 2019). The real estate company that borrows the money acquires ownership of the assets and gives it as a mortgage guarantee to a third party (Special Purpose Vehicle) that holds them as collateral for all creditors (Ernst \& Young, 2019).

As the profitability under this model is fixed and the investors do not have ownership of the project, they are not entitled to any extraordinary income generated by that project. On the other hand, in the event of a failure, the impact will not be so great. In this case, a lower risk also implies lower returns (see Figure 4).

Another risk of investments through RECF platforms is the lack of liquidity. Both in the case of financing through loans and in the case of financing through participation in the share capital, investors cannot withdraw the money before the completion of the project. Delivorias (2017) raises this issue by saying that there is a need for an efficient secondary market in which investors who own shares can trade freely. However, in recent years, platforms have begun to add a secondary market option, that allow investors to buy and sell pre-financed loans. 


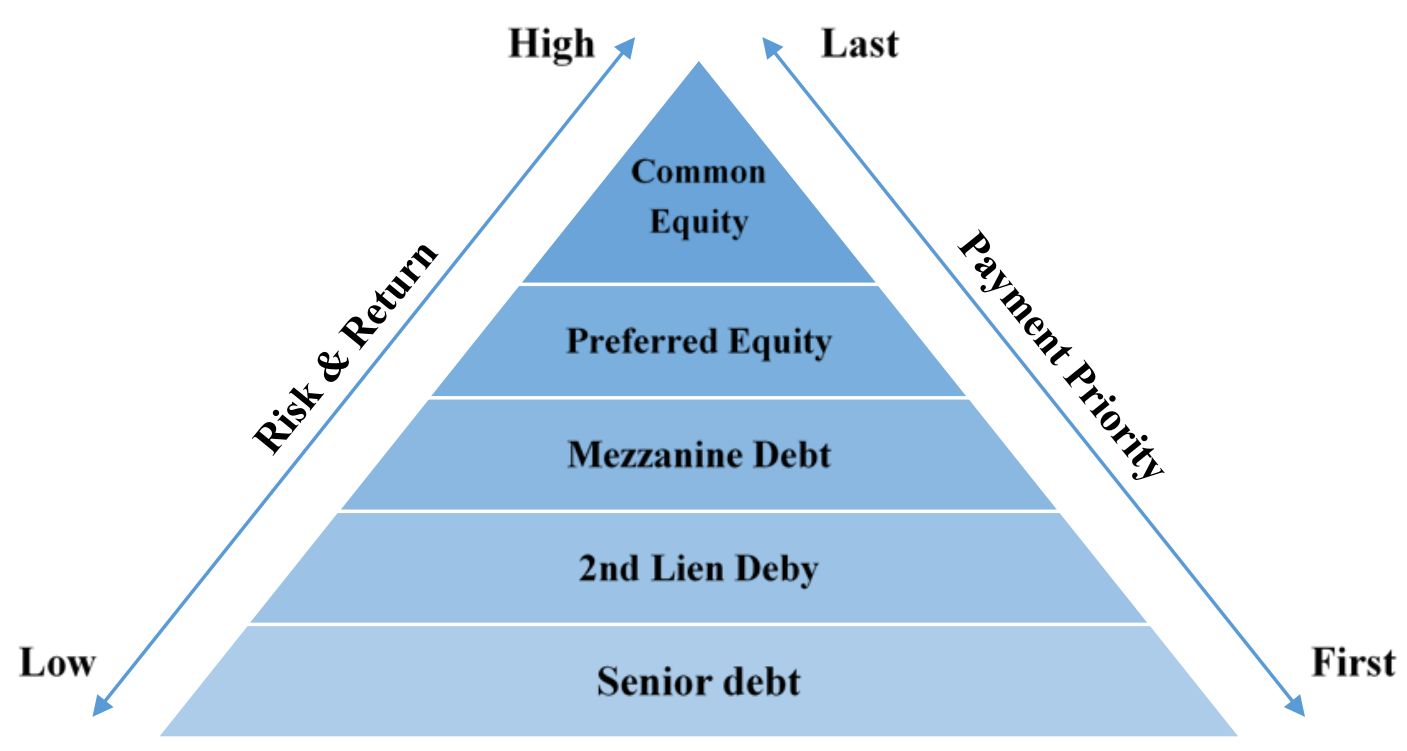

Figure 4. The risk \& return relationship in RECF Source: adapted from Schmidt (2019)

Vogel and Moll (2014) identify a risk associated with investors who overestimate their expertise. Advertising on various platforms leads to the idea that anyone can invest in real estate, which gives individuals confidence to invest through them. The best approach is to consult a specialist in the field to make a decision about the property in which they want to invest.

In addition to the risks associated with RECF platforms, there are many other risks in the real estate sector, from specific risks such as site concentration, construction and execution risks, to business, financial or liquidity risks (Khumpaisal, 2011). At the same time, fluctuations in the Real Estate sector, sector trends or events with an impact on the entire economy: global crises, pandemics (as Covid-19) are risks that both investors and project promoters must take into account.

\section{COMPARATIVE ANALYSIS OF THE LARGEST EUROPEAN REAL ESTATE CROWDFUNDING PLATFORMS}

Although real estate crowdfunding platforms began to appear around 2010 in the USA, they began to take a strong shape on the European market as well. To better understand the current state of these platforms, we conducted a comparative analysis of seven major European platforms (see Table 1). The criteria that were the basis for choosing these platforms were: to have the option of investing in real estate, to provide reports on the main indicators, and the last criterion to have a considerable raised equity. Thus, the analyzed platforms were: Mintos, EstateGuru, Housers, Crowdestate, Rendity, Bulkestate, Reinvest24. These were the main source of data.

As expected, the founding year is relatively recent, from 2014 Crowdestate and EstateGuru, to 2018 Reinvest 24. During this period, investors began to trust these alternative sources of investment, a fact reflected by the continuous growth of the segment. So far, these types of investments have not gone through major economic crises in order to test their volatility, but the 2020 Covid-19 pandemic may be the first time that could test the stability and safety of these platforms.

In terms of the amounts attracted, the platform that occupies the first place is Mintos, with 5.6 billion euros, followed by EstateGuru, with 260 million euros and Housers with 118 million euros. 
Table 1. Comparative analysis of the largest European real estate crowd funding platforms

\begin{tabular}{|c|c|c|c|c|c|c|c|c|c|c|}
\hline $\begin{array}{c}\text { RECF } \\
\text { platform } \\
\text { (Web site } \\
\text { name) }\end{array}$ & Country & $\begin{array}{c}\text { Year of } \\
\text { foundation }\end{array}$ & $\begin{array}{l}\text { Equity } \\
\text { raised }\end{array}$ & $\begin{array}{c}\text { No. of } \\
\text { investors }\end{array}$ & $\begin{array}{l}\text { Investment } \\
\text { types }\end{array}$ & $\begin{array}{l}\text { Miniumum } \\
\text { invest } \\
\text { amount }\end{array}$ & $\begin{array}{l}\text { Average } \\
\text { return }\end{array}$ & $\begin{array}{l}\text { BuyBack } \\
\text { guarantee }\end{array}$ & $\begin{array}{l}\text { Secondary } \\
\text { Market }\end{array}$ & $\begin{array}{l}\text { Auto } \\
\text { Invest }\end{array}$ \\
\hline Mintos & Latvia & 2015 & $\begin{array}{r}\sim 5.699 \\
\mathrm{M} €\end{array}$ & $\sim 342.701$ & $\begin{array}{l}\text { Business \& } \\
\text { Personal } \\
\text { loans }\end{array}$ & $10 €$ & $12,4 \%$ & Yes & Yes & Yes \\
\hline $\begin{array}{l}\text { EstateGu } \\
\text { ru }\end{array}$ & Estonia & 2014 & $\begin{array}{r}\sim 260 \\
\mathrm{M} €\end{array}$ & $\sim 62.954$ & $\begin{array}{l}\text { Real Estate } \\
\text { loans }\end{array}$ & $50 €$ & $11,6 \%$ & No & Yes & Yes \\
\hline Housers & Spain & 2015 & $\begin{aligned} \sim & 118 \\
& \mathrm{M} €\end{aligned}$ & 124.033 & $\begin{array}{l}\text { Real Estate } \\
\text { loans }\end{array}$ & $50 €$ & $8,66 \%$ & No & Yes & Yes \\
\hline $\begin{array}{l}\text { Crowdest } \\
\text { ate }\end{array}$ & Estonia & 2014 & $\begin{array}{r}\sim 97 \mathrm{M} \\
€\end{array}$ & $\sim 51.553$ & $\begin{array}{l}\text { Real Estate } \\
\text { loans \& } \\
\text { Business } \\
\text { loans }\end{array}$ & $100 €$ & $13,7 \%$ & No & Yes & Yes \\
\hline Rendity & Austria & 2015 & $\begin{array}{r}\sim 43 \\
\mathrm{M} €\end{array}$ & $\sim 3.796$ & $\begin{array}{l}\text { Rental Real } \\
\text { Estate }\end{array}$ & $500 €$ & $6,1 \%$ & No & Yes & Yes \\
\hline $\begin{array}{l}\text { Bulkestat } \\
\text { e }\end{array}$ & Estonia & 2016 & $\begin{array}{r}\sim 14 \mathrm{M} \\
€\end{array}$ & $\sim 5.000$ & $\begin{array}{l}\text { Real Estate } \\
\text { loans }\end{array}$ & $50 €$ & $14,7 \%$ & No & No & Yes \\
\hline $\begin{array}{l}\text { Reinvest } \\
24\end{array}$ & Estonia & 2018 & $\begin{array}{r}\sim 12 \\
\mathrm{M} €\end{array}$ & $\sim 5.900$ & Equity & $100 €$ & $14,6 \%$ & No & No & No \\
\hline
\end{tabular}

Source: own elaboration

Most types of investments are Real Estate loans, with the exception of Reinvest24 which operates on the equity model. Mintos also offers business loans, personal loans, car loans, agricultural loans, which explains its performance in terms of amounts attracted and number of investors. The proportion of operating models of crowdfunding platforms in Europe, according to Schmidt (2019b) is as follows: $79.1 \%$ lending-based crowdfunding, $13.9 \%$ equity-based crowdfunding, $4.7 \%$ rewardbased crowdfunding, and $1.6 \%$ donation-based crowdfunding.

The minimum amount for investment starts from 10 euros for the Mintos platform and reaches 500 euros for the Austrian platform Rendity. This small amount, except in the case of Rendity, allows investors to diversify their investments on several projects or several countries.

The average yield for these platforms is $11.68 \%$, in which the minimum yield of $6.1 \%$ is offered by Rendity, and the maximum of 14.7 offered by the Bulkestate platform. These yields exceed the yields offered by bank deposits, and in some cases those offered by bonds or shares, which makes them attractive to investors.

In the case of the analyzed platforms, only Mintos offers the buyback guarantee facility. A buyback guarantee is an agreement between the originator of the loan and the lender, in order to protect the lender against overdue loans and non-repayable loans from the borrower. The initiator of the loan is the person who offers the buyback guarantee (Schmidt, 2019c). However, in most platforms, members' investments are held in SPVs, which are not part of the platform's assets. In the case of Crowdestate, to correlate risk with investment projects, the RECF platform provides a risk rating for each project from A1 to C5, where A1 is very safe and C5 very risky.

As a major risk was the lack of liquidity and investors could not withdraw the money before the project deadline, crowdfunding service providers recently began to develop a new facility for investors, respectively, a secondary market. Secondary markets for crowdlending are markets that allow investors to buy and sell pre-financed loans. In the case of equity platforms, they generally allow investors who have purchased shares through these RECFs to trade them on the market. 
The self-invest option is gaining attention in real estate crowdfunding platforms because it is a way for investors to gain easy access to transactions that meet their investment criteria. The EstateGuru platform describes this feature as follows: "The main keywords for the Auto Invest feature are comfort, speed and automation. Auto Invest ensures you will not miss an investment opportunity due to high demand and the investment will be placed based on your chosen criteria automatically, without you having to stress about it. Auto Invest enables you to build a diversified portfolio, in which all the projects are chosen by a professional team who stands for the success of your investments. Auto Invest enables you to reinvest your income at the earliest opportunity. This way you start earning interest on committed funds as soon as possible.”

Although there is a growing interest in these platforms in the European market, they are still poorly developed compared to the world's economies. On the European Commission's website, the biggest obstacle is the lack of common rules across the EU. This raises operational and compliance costs, which prevents them from expanding beyond borders.

Based on this situation, on 5 October 2020 the European Parliament approved Regulation (EU) 2020/1503, which contains new rules that will allow crowdfunding platforms to easily provide services on the EU market. This will attract a larger fund of potential investors, as well as provide investors with a wider range of projects and better protection. Thus, crowdfunding platforms operating in several EU countries will have to follow a single set of basic rules, instead of different rules in each country. The rules will apply to European crowdfunding service providers raising up to EUR 5 million per project per year.

\section{CONCLUSIONS}

Crowdfunding platforms represent a new paradigm in the field of real estate investments. If until now such investments were inaccessible to small investors, RECF platforms allow them to diversify their investment portfolio by financing real estate projects around the world with small amounts. The average return on these investments is between 10 and $15 \%$, which is an attractive financial instrument for retail investments.

The developer can receive financing independently from a bank or a traditional creditor, and at the same time the associated time and costs are reduced. Also, the project beneficiary can create a network of business partners, which will contribute to the success of the project.

As any investment comes with an associated risk, investments through RECF platforms also present certain risks that must be considered.

In the equity model, the return on investment is closely correlated with the value of the shares held. If a project fails, investors can lose some or all of the money. Moreover, a project can last for several years, and all this time the money cannot be withdrawn.

In the loan-based model, the common risks are due to late payments and the lack of registration of a mortgage on the loan. Instead, the yield is fixed, known from the beginning, and the risks are slightly lower. This makes it the most used model for the crowdfunding real estate segment.

In addition, the risks specific to the real estate sector such as those related to execution, business, financial and liquidity, but also to the fluctuations of the real estate sector must be taken into account.

Regarding the European market, there are currently some big players on the crowdfunding real estate market, and more and more are appearing to cover the demand for alternative financing. The market is still young, with small volumes, but offers investors returns of up to $15 \%$.

At present, European real estate crowdfunding platforms are facing difficulties in expanding abroad due to the different regulations of each country. In this direction, the European Parliament approved in October 2020 a regulation targeting crowdfunding platforms, thus allowing them to offer services in EU member states under the same regulation. 
Looking to the future, there are many development perspectives: various combinations of financing models, attracting projects from public administrations, financing projects that have exceeded the projected budget, etc.. Certainly, the direction will be a positive one, and what supports this growth is the technology and the variety of applications that can be incorporated. The services will be improved qualitatively and quantitatively, and the risks will be reduced, so that they will inspire credibility to the promoters and investors.

RECF crowdfunding will continue to develop worldwide, mainly due to market developments. As a result, investors' appetite for this type of financial product is gradually increasing, attracting new players to the fintech market, including the new generations.

\section{REFERENCES}

Baker, D. (2008). The housing bubble and the financial crisis. Realworld economics review, 46, 7381.

Borrero-Domínguez, C., Cordón-Lagares, E. \& Hernández-Garrido, R. (2020). Sustainability and Real Estate Crowdfunding: Success Factors. Sustainability. 12. DOI: 5136. 10.3390/su12125136.

Cassell, W. (2019). Are Fundrise's eREITs Right for You?. Investopedia. Retrieved October 28, 2020 https://www.investopedia.com/articles/investing/123115/fundrises-new-ereit-rightyou.asp.

Crowdestor. (n.d.). The Economics of Delayed Payments. Retrieved October 29, 2020, from https://crowdestor.com/en/post/The_Economics_of_Delayed_Payments.

Crowdfunding. (2020). In Oxford Online Dictionary. Retrieved October 24, 2020 from https://en.oxforddictionaries.com/definition/ crowdfunding.

Crowdfunding-platforms. (2020). Best Crowdlending Platforms in Europe 2020. Retrieved October 28, 2020, from https://crowdfunding-platforms.com/top-crowdlending-platforms-europecomparison.

Delivorias, A. (2017). Crowdfunding in Europe. Introduction and state of play. European Parliamentary Research Service.

Ernst \& Young. (2019). Real Estate Crowdfunding. Introduction to an alternative way of investing. Retrieved October 24, 2020 from https://www.ey.com/en_gl.

Eur-lex. (n.d.). Regulation (Eu) 2020/1503 Of The European Parliament and of the Council of 7 October 2020 on European crowdfunding service providers for business, and amending Regulation (EU) 2017/1129 and Directive (EU) 2019/1937. Official Journal of the European Union. Retrieved October 20, 2020, from https://eur-lex.europa.eu/legalcontent/EN/TXT/?uri=CELEX\%3A32020R1503.

European Central Bank. (2015). The Impact of the CRR and CRD IV on Bank Financing: Eurosystem Response to the DG FISMA Consultation Paper; European Central Bank: Frankfurt, Germany.

European Comission. (n.d.). What is crowdfunding?. Retrieved October 29, 2020, from https://ec.europa.eu/info/business-economy-euro/growth-and-investment/financinginvestment/crowdfunding_en.

Garcia-Teruel, R. (2019). A legal approach to real estate crowdfunding platforms. Computer Law \& Security Review. 35. 10.1016/j.clsr.2019.02.003.

Hu, S. (2017). Intelligent REIT's in the information age. Procedia Computer Science, No. 111, pp. 329-338.

Khumpaisal, S. (2011). A Classification of Risks in Real Estate Development Business. Journal of architectural and planning research. 8, 1-8.

Massolution. (2015). 2015CF-RE Crowdfunding for Real Estate. Retrieved October 26, 2020 from http://reports.crowdsourcing.org/index.php?route=product/product\&product_id=52. 
Schmidt, J. (2019a). The Ultimate Guide to Real Estate Crowdfunding with Examples. Retrieved October 27, 2020, from https://p2pmarketdata.com/real-estate-crowdfunding-guide/.

Schmidt, J. (2019b). Common EU Rules for Crowdfunding: Regulation on European P2P Platforms Explained. Retrieved October 28, 2020, from https://p2pmarketdata.com/crowdfundingregulation-eu/.

Schmidt, J. (2019c). What is Buyback Guarantee in P2P Lending?. Retrieved October 28, 2020, from https://p2pmarketdata.com/what-is-buyback-guarantee-p2p-lending/.

Schweizer, D. \& Zhou, T. (2016). Do Principles Pay in Real Estate Crowdfunding?. 10.13140/RG.2.2.17238.86083.

Shahrokhi, M. (2018). Crowdfunding in Real Estate: Evolutionary \& Disruptive. Managerial Finance, 46(6), 785-801.

Vogel, J. \& Moll, B. (2014). Crowdfunding for Real Estate. The Real Estate Finance Journal, Summer-Fall, summer-fall, 5-16. 